\title{
THE DEVELOPMENT OF THREE TIER TEST (TTT) INSTRUMENTS TO IDENTIFY STUDENTS' MISCONCEPTIONS ON MATERIAL IN ELEMENTARY SCHOOL
}

\author{
Suci Zakiah Dewi, Irfan Hilman \\ Universitas Garut, Jl. Raya Samarang No.52A \\ Correspondence Email: suci@uniga.ac.id
}

\begin{abstract}
The purpose of this study is to develop the assessment instruments used in testing the level of science misconceptions in high grade elementary school. The instrument used is a Three-tier test (TTT) This research is a Research and Development (R\&D) research that is a method of conducting research for research that produces a product, and testing the effectiveness of the product. The research stages are as follows: (1) Data Collection and Literature Studies, (2) Product Description and Design, (3) Small Scale Trials, (4) Product Analysis and Revision, (5) Broad-Scale Trials, and (6) Product Analysis and Revision. The research conducted at SDN 5 Sukagalih, Tarogong Kidul District, Garut on a small scale and for a large scale at SDN 1,2,3,4 and 5 Sukagalih, Tarogong Kidul District, Garut. Based on the results of the research obtained data that by using TTT instruments teachers can find out how much quantity of students are misconceptions, trials are conducted on a small scale and large scale and each is carried out 2 stages, namely the stage before the revision and after the revision of the instrument. The results of phase I tests on a large scale many students experienced misconceptions of $62.7 \%$ and the phase II test after instrument revision showed a significant decrease to $32.65 \%$ of students who experienced misconceptions, the presentation of a decrease in the quantity of misconceptions for large scale was $52.86 \%$. the result was quite significant compared to the small scale which decreased by only $24.61 \%$. The results showed that by using TTT techniques teachers will easily identify the quantity of students who misconception and for the next the teacher will provide treatment to students to lower the quantity.
\end{abstract}

\section{Keywords}

misconceptions, science, elementary school, three tier test

\section{A. INTRODUCTION}

In classroom learning especially science, not a few students build conceptions that are irrelevant to scientific facts. So in the end the concept that was built is wrong and it is commonly called misconceptions ${ }^{1}$, some other terms such as preconception $^{2}$ and common sense concepts ${ }^{3}$. The erroneous knowledge is owned continuously and is believed to be the truth to explain various

\footnotetext{
${ }^{1}$ Helm, H. (1980). Misconceptions in Physics Amongst South African Students. Physics Education, 15(2): 92-105.

${ }^{2}$ Boeha B. B. (1990). Aristotle, Alive and Well in Papua New Guinea science classrooms. Physics Education, 25:280-283.

${ }^{3}$ Halloun IA, dan Hestenes D. (1985). Common sense concepts about motion. American Journal. Physics, 53:1056-1065.
}

phenomena ${ }^{4}$. According to Berg the main principle in misconception correction is that learners are given a learning experience that shows their concept conflict with natural events, a contradiction of new experiences with the old concept ${ }^{5}$. Another point of view is that misconceptions are the idea children "have incorporated into their cognitive structure that they use to

\footnotetext{
${ }^{4}$ Sabo, H. C., Goodhew, L. M., \& Robertson, A. D.

2016.University Student Conceptual Resources for

Understanding Energy.Physical Review Physics Education

Research, 12(1): 0101261-01012628.

${ }^{5}$ Tyas, dkk. (2013). Penggunaan Strategi POE (Predict, Discuss, Observe) untuk Memperbaiki Miskonsepsi Fisika. [online]. Tersedia di :

http://id.portalgaruda.org/index.php?ref=browse \&mod=viewa $\underline{\text { rticle\&article }=342970 .}$. Jurnal Pendidikan Sains Pendidikan Kimia Vol 1, No 1 (2013). Diakses pada 10 Oktober 2020.
} 
understand and make predictions about the world ${ }^{6}$.

At the elementary school level in identifying misconceptions and understanding concepts, a special test is also required, one of which is the Three Tier Test (TTT). The advantage of TTT is that it does not take much time and can be used to know students who do not understand the concept of answering questions by guessing7. There are categories of TTT as in the form of the following table ${ }^{8}$ :

6 Andre, T. \& Ding, P. (1991). Student misconceptions, declarative knowledge, stimulus conditions, and problem solving in basic electricity. Contemporary Educational Psychology vol 16: 303-313.

${ }^{7}$ Dewi, Suci Zakiah. (2016). Penerapan Strategi Predict, Discuss, Explain, Observe, Discuss, Explain (PDEODE) pada Pembelajaran IPA SD untuk meningkatkan pemahaman Konsep dan Menurunkan Kuantitas Siswa yang Miskonsepsi pada Materi Perubahan Wujud Benda di Kelas V. Tesis. Bandung: Jurusan Pendidikan Dasar SPS UPI Bandung.

8 Muliyani, R. (2014). Pengaruh penerapan model Pembelajaran predict-observe- explain (POE) berbantuan refutation text terhadap peningkatan pemahaman konsep dan penurunan kuantitas miskonsepsi siswa SMP pada materi fluida statis. Tesis. Bandung: Jurusan Pendidikan Fisika SPS UPI Bandung. 
Table 1

Forms of Misconception

\begin{tabular}{|c|c|c|c|}
\hline Level I & Level II & Level III & Categories \\
\hline Correct & Correct & Sure & Correctly concept \\
\hline Correct & Correct & Not Sure & $\begin{array}{l}\text { Not really understand } \\
\text { the concept }\end{array}$ \\
\hline Correct & False & Sure & Misconception \\
\hline Correct & False & Not Sure & Guessing \\
\hline False & False & Sure & Misconception \\
\hline False & False & Not Sure & Blind concept \\
\hline False & Correct & Sure & Misconception \\
\hline False & Correct & Not Sure & Misconception \\
\hline
\end{tabular}

Research at the basic level on material forms of objects has also been carried out in MIN Cicendo Bandung ${ }^{9}$ and the results are many siswqa that also experience misconceptions and caused by several factors, one of which is the method used in teaching teachers as long as kuran material can be understood by students.

According to the standard content of subjects ${ }^{10}$ material form objects in elementary school in general consists of: (1) Various forms and properties of objects (2) Changes in the form of solid objects, liquid and gas consisting of melting, disfies, freezes, evaporates, condenses and crystallizes.

The expected result of this research is the extent to which the instruments developed can know the condition and quantity of misconceptions of elementary school students so that if the numbers found are alarming then it needs to be

\footnotetext{
${ }^{9}$ Dewi, Suci Zakiah. (2016). Penerapan Strategi Predict, Discuss, Explain, Observe, Discuss, Explain (PDEODE) pada Pembelajaran IPA SD untuk meningkatkan pemahaman Konsep dan Menurunkan Kuantitas Siswa yang Miskonsepsi pada Materi Perubahan Wujud Benda di Kelas V. Tesis. Bandung: Jurusan Pendidikan Dasar SPS UPI Bandung.

10 Permendiknas. (2013). Peraturan menteri pendidikan nasional republik indonesia tahun 20013 standar isi pendidikan. Diakses dari: http://bsnp-indonesia.org/id/wpcontent/uploads/2013/06/Permendikbud-Nomor-64-tahun2013-tentang_Standar-Isi.zip. 3 Oktober 2020.
}

followed up with remediation by the teacher concerned.

This research is a research and development (R\&D) is a method of conducting research for research that produces a product, and testing the effectiveness of the product. The research stages are as follows: (1) Data Collection and Literature Studies, (2) Product Description and Design, (3) Small Scale Trials, (4) Product Analysis and Revision, (5) Broad-Scale Trials, and (6) Product Analysis and Revision. The resulting product is a form of Three Tier Test instrument in the form of objects in high-grade elementary school, which has been tested both on a small and large scale.

The instrument used is a form of Three Tier Test (TTT) where each question item has 3 stages of answer. After the results of the answers collected and then processing the data using quantitative analysis. The subject of this study was a high-class student at SD Negeri in the tarogong area of Garut.

\section{B. RESULTS AND DISCUSSION \\ 1. RESULTS}


This research was conducted in the high class of SDN 5 Sukagalih for smallscale data collection, then for largescale data collection was conducted at SDN 1, 2, 3, 4, and 5 Sukagalih Tarogong Kidul Subdistrict in Garut
Regency in March-June 2020. Data Number of Instrument Items used to measure the quantity of misconceptions consists of 19 question items as seen in the following table:

Table 2

The Distribution of Misconceptions about Changes in The Shape of Objects

\begin{tabular}{|c|c|c|c|c|}
\hline \multirow{3}{*}{$\begin{array}{c}\text { The } \\
\text { Distribution of } \\
\text { Question Items }\end{array}$} & \multicolumn{3}{|c|}{ Material Indicators } & \multirow[b]{2}{*}{ Total } \\
\hline & $\begin{array}{c}\text { Solid } \\
\text { Object }\end{array}$ & $\begin{array}{l}\text { Liquid } \\
\text { Object }\end{array}$ & $\begin{array}{c}\text { Gas } \\
\text { Object }\end{array}$ & \\
\hline & $\begin{array}{l}4,5,6,7,8 \\
9,10,15,16, \\
17\end{array}$ & $\begin{array}{l}1,2,3,11, \\
18\end{array}$ & $\begin{array}{l}12,13,14, \\
19\end{array}$ & 19 \\
\hline
\end{tabular}

The validity test of the instruments in this study was based on expert judgement. As Fraenkel and Wallen stated that validity can be done by someone who will see the content and format of which instruments are appropriate and which are not, a person in question is a person who knows about what will be measured so that the instrument is feasible, therefore the validity of the question and indicators is carried out by lecturers who are experts in their field ${ }^{11}$. In identifying the occurrence of misconceptions, the Three Tier Test (TTT) method with three levels of testing is applied.

The decrease in the quantity of misconceptions in question is a decrease in the number of students who experience misconceptions in each concept tested. To find out the decrease, the formula adapted from the normalized gain formula developed by Suhandi is:

11 Muliyani, R. (2014). Pengaruh penerapan model Pembelajaran predict-observe- explain (POE) berbantuan refutation text terhadap peningkatan pemahaman konsep dan penurunan kuantitas miskonsepsi siswa SMP pada materi fluida statis. Tesis. Bandung: Jurusan Pendidikan Fisika SPS UPI Bandung. 
Descriptions :

$$
\text { PKM }=\frac{\% \text { MPretest }-\% \text { MPostest }}{\% \text { MPretest }-\% \text { MIdeal }} \times 100 \%
$$

$\mathrm{PKM}=$ Penurunan kuantitas miskonsepsi

$\%$ MPretest $=$ Percentage of students who experience misconceptions in a concept before treatment.

$\%$ MPostest $=$ Percentage of students who experience misconceptions in a concept after treatment.

$\%$ MIdeal = Ideal expectation of misconceptions $(0 \%)$

The distribution of scientific concepts and misconceptions contained in the instrument details are as follows:

Table 3

Distribution of Scientific Concepts and Misconceptions on The Problem

\begin{tabular}{|c|c|c|c|}
\hline $\begin{array}{l}\text { Number of } \\
\text { Concepts }\end{array}$ & Scientific Concepts & Misconceptions & $\begin{array}{l}\text { Number of } \\
\text { Questions }\end{array}$ \\
\hline 1 & $\begin{array}{l}\text { The concept of } \\
\text { condensation on glass } \\
\text { walls containing water } \\
\text { and ice cubes. }\end{array}$ & $\begin{array}{l}\text { Dew points on the outer } \\
\text { surface of the container } \\
\text { come from solid objects } \\
\text { that melt inside the } \\
\text { container }\end{array}$ & 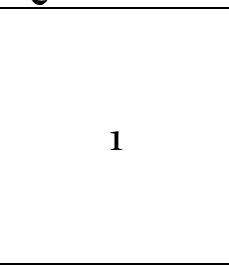 \\
\hline 2 & $\begin{array}{l}\text { The volume of liquid } \\
\text { objects will increase } \\
\text { when frozen but the } \\
\text { mass remains. }\end{array}$ & $\begin{array}{c}\text { The volume and mass of } \\
\text { liquid objects will increase } \\
\text { when they freeze }\end{array}$ & 2 \\
\hline 3 & $\begin{array}{l}\text { Liquid objects will } \\
\text { undergo evaporation } \\
\text { and produce } \mathrm{H}_{2} \mathrm{O} \\
\text { molecules in them }\end{array}$ & $\begin{array}{c}\text { Bubbles in liquid objects } \\
\text { undergoing evaporation } \\
\text { are derived from the cause } \\
\text { of evaporation. }\end{array}$ & 3,19 \\
\hline 4 & $\begin{array}{c}\text { Characteristics change } \\
\text { in physics is not } \\
\text { producing new } \\
\text { substances }\end{array}$ & $\begin{array}{c}\text { The only feature of physics } \\
\text { change is the change that } \\
\text { can return to its original } \\
\text { form. }\end{array}$ & 4 \\
\hline 5 & $\begin{array}{c}\text { Plastics in the } \\
\text { manufacture mixed } \\
\text { with organic materials } \\
\text { can one day be } \\
\text { destroyed }\end{array}$ & $\begin{array}{c}\text { Plastic cannot be crushed / } \\
\text { damaged }\end{array}$ & 5 \\
\hline 6 & $\begin{array}{l}\text { Hard is the ability of } \\
\text { an object to withstand } \\
\text { scratches and strong is } \\
\text { the ability of the object } \\
\text { to withstand the load }\end{array}$ & $\begin{array}{l}\text { Hard and strong is a term } \\
\text { that has the same meaning }\end{array}$ & 6 \\
\hline 7 & $\begin{array}{c}\text { One of the } \\
\text { characteristics of solid } \\
\text { objects is that it does }\end{array}$ & $\begin{array}{l}\text { Solid objects that follow } \\
\text { the container and change } \\
\text { shape due to the influence }\end{array}$ & 7,8 \\
\hline
\end{tabular}




\begin{tabular}{|c|c|c|c|}
\hline $\begin{array}{c}\text { Number of } \\
\text { Concepts }\end{array}$ & Scientific Concepts & Misconceptions & $\begin{array}{l}\text { Number of } \\
\text { Questions }\end{array}$ \\
\hline & $\begin{array}{l}\text { not change shape } \\
\text { when changing places } \\
\text { if without the } \\
\text { influence of press force } \\
\text { even though the size is } \\
\text { small and soft }\end{array}$ & $\begin{array}{c}\text { of force press is not a solid } \\
\text { object }\end{array}$ & \\
\hline 8 & $\begin{array}{l}\text { Most of the solids are } \\
\text { strong and very hard } \\
\text { but there are some soft } \\
\text { solids. }\end{array}$ & $\begin{array}{l}\text { The solid must be hard, } \\
\text { strong and not soft. }\end{array}$ & 9 \\
\hline 9 & $\begin{array}{c}\text { Mass is related to the } \\
\text { density of matter in an } \\
\text { object }\end{array}$ & $\begin{array}{l}\text { Mass is associated with the } \\
\text { term 'large' and is thus } \\
\text { associated with the size or } \\
\text { volume of an object. }\end{array}$ & 10 \\
\hline 10 & $\begin{array}{l}\text { Liquid objects can } \\
\text { have a greater mass } \\
\text { than solids if the } \\
\text { density of matter is } \\
\text { greater than solid } \\
\text { objects }\end{array}$ & $\begin{array}{l}\text { Liquid objects always have } \\
\text { a lighter mass than solids. }\end{array}$ & 11 \\
\hline 11 & $\begin{array}{l}\text { Air consists of various } \\
\text { gases and is not } \\
\text { separated between the } \\
\text { dangerous and the } \\
\text { harmless }\end{array}$ & $\begin{array}{l}\text { Air consists of one } \\
\text { substance and differs from } \\
\text { gas, because the air is good } \\
\text { and the gas is toxic. }\end{array}$ & 12,13 \\
\hline 12 & $\begin{array}{l}\text { Gas is composed of } \\
\text { material that is very } \\
\text { small in size and has a } \\
\text { very small mass so that } \\
\text { the overall mass of gas } \\
\text { is very light. }\end{array}$ & Gas has no mass or weight. & 14,17 \\
\hline 13 & $\begin{array}{l}\text { Dissolution involves } \\
\text { two types of so-called } \\
\text { sugar dissolving } \\
\text { substances in hot } \\
\text { water as solvents, } \\
\text { while melting is } \\
\text { different from } \\
\text { dissolution. }\end{array}$ & $\begin{array}{l}\text { Dissolution and melting } \\
\text { are the same events. }\end{array}$ & 15 \\
\hline 14 & $\begin{array}{l}\text { Decomposing objects, } \\
\text { the material will } \\
\text { decompose into } \\
\text { simpler substances } \\
\text { and be released into } \\
\text { the environment in }\end{array}$ & $\begin{array}{l}\text { The rotting object will } \\
\text { disappear. }\end{array}$ & 16 \\
\hline
\end{tabular}




\begin{tabular}{|c|c|c|c|}
\hline $\begin{array}{c}\text { Number of } \\
\text { Concepts }\end{array}$ & Scientific Concepts & Misconceptions & $\begin{array}{c}\text { Number of } \\
\text { Questions }\end{array}$ \\
\hline & equal quantities & & 18 \\
\hline 15 & $\begin{array}{c}\text { In addition to solar } \\
\text { heating, the wind can } \\
\text { also help evaporation } \\
\text { of sea water. }\end{array}$ & $\begin{array}{c}\text { Evaporation occurs only } \\
\text { when there is sunlight. }\end{array}$ & 18 \\
\hline
\end{tabular}

The following is a recapitulation of the results of TTT analysis that can distinguish students who experience misconceptions, understand concepts, and do not understand concepts.

Table 4

Recapitulation of TTT Analysis Results on a Small Scale

\begin{tabular}{|c|c|c|c|c|c|c|}
\hline \multirow{2}{*}{$\begin{array}{c}\text { Concepts } \\
\text { Number }\end{array}$} & \multicolumn{2}{|c|}{$\begin{array}{c}\text { \%Students' } \\
\text { Misconceptions Total }\end{array}$} & $\begin{array}{c}\text { \% Students' } \\
\text { Understanding } \\
\text { Concepts Total }\end{array}$ & \multicolumn{2}{c|}{$\begin{array}{c}\text { \% Students' } \\
\text { Blind Idea of } \\
\text { Concepst Total }\end{array}$} \\
\cline { 2 - 7 } & Level I & Level II & $\begin{array}{c}\text { Level } \\
\text { I }\end{array}$ & $\begin{array}{c}\text { Level } \\
\text { II }\end{array}$ & $\begin{array}{c}\text { Level } \\
\text { I }\end{array}$ & Level II \\
\hline 1 & 30 & 17 & 70 & 83 & o & o \\
\hline 2 & 90 & 53 & 0.3 & 47 & 0.3 & O \\
\hline 3 & 52 & 42 & 22 & 78 & 0.7 & 0.1 \\
\hline 4 & 67 & 50 & 23 & 47 & 0.3 & 0.3 \\
\hline 5 & 60 & 50 & 27 & 50 & 0.7 & 0 \\
\hline 6 & 73 & 67 & 17 & 33 & 0.7 & 0 \\
\hline 7 & 55 & 53 & 48 & 47 & 0.7 & 0 \\
\hline 8 & 50 & 43 & 37 & 53 & 0.3 & 0 \\
\hline 9 & 67 & 27 & 23 & 63 & 0.7 & 0 \\
\hline 10 & 80 & 53 & 0.7 & 33 & 10 & 0.7 \\
\hline 11 & 60 & 38 & 18 & 50 & 10 & 0.8 \\
\hline 12 & 77 & 70 & 0.8 & 15 & 0.8 & 0.8 \\
\hline 13 & 73 & 67 & 23 & 27 & 0.3 & 0.3 \\
\hline 14 & 50 & 33 & 37 & 60 & 0.7 & 0.7 \\
\hline 15 & 90 & 83 & 0 & 0.7 & 0.7 & 0.7 \\
\hline
\end{tabular}

Based on data in Table 4, the percentage of students on a small scale who experience misconceptions decreases. The decrease in the number of students experiencing misconceptions occurred in the whole concept of changing the form of objects. 


\begin{tabular}{|c|c|c|c|c|c|c|}
\hline \multirow{2}{*}{$\begin{array}{c}\text { Concepts } \\
\text { Number }\end{array}$} & \multicolumn{2}{c|}{$\begin{array}{c}\text { \%Students' } \\
\text { Misconceptions Total }\end{array}$} & $\begin{array}{c}\text { \% Students' } \\
\text { Understanding } \\
\text { Concepts Total }\end{array}$ & \multicolumn{2}{c|}{$\begin{array}{c}\text { \% Students' } \\
\text { Blind Idea of } \\
\text { Concepst Total }\end{array}$} \\
\cline { 2 - 7 } & Level I & Level II & $\begin{array}{c}\text { Level } \\
\text { I }\end{array}$ & Level II & $\begin{array}{c}\text { Level } \\
\text { I }\end{array}$ & Level II \\
\hline 1 & 67 & 17 & 30 & 83 & o & o \\
\hline 2 & 67 & 23 & 10 & 70 & 13 & 0.3 \\
\hline 3 & 19 & 12 & 25 & 90 & 10 & 0.3 \\
\hline 4 & 67 & 27 & 0 & 57 & 20 & 13 \\
\hline 5 & 63 & 33 & 27 & 60 & 10 & 10 \\
\hline 6 & 73 & 50 & 0 & 43 & 17 & 0.6 \\
\hline 7 & 75 & 43 & 15 & 48 & 10 & 0.5 \\
\hline 8 & 70 & 33 & 13 & 57 & 10 & 0.3 \\
\hline 9 & 50 & 33 & 27 & 60 & 10 & 0.3 \\
\hline 10 & 60 & 47 & 0.5 & 43 & 27 & 10 \\
\hline 11 & 83 & 27 & 22 & 92 & 10 & 0.3 \\
\hline 12 & 80 & 50 & 0.5 & 40 & 12 & 0.8 \\
\hline 13 & 70 & 47 & 20 & 47 & 10 & 0.7 \\
\hline 14 & 23 & 0.7 & 33 & 77 & 10 & 0.3 \\
\hline 15 & 73 & 47 & 10 & 47 & 10 & 0.3 \\
\hline
\end{tabular}

To find out the significance of differences in the quantity of misconceptions in the concept of changes in the form of experimental class objects and control classes, a statistical test of the hypothesis has been conducted. The following is a diagram that presents the percentage of the number of students experiencing an average decrease in the quantity of misconceptions per concept on the concept of tangible objects on a small and large scale.

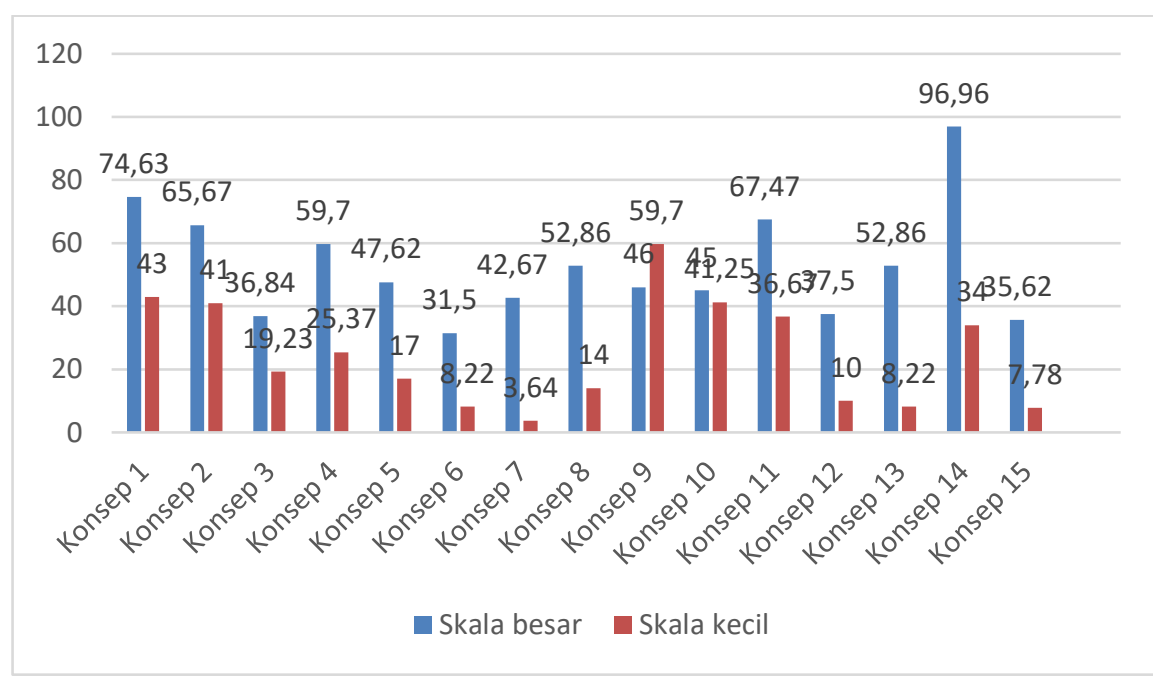

Figure 1

The Percentage Decrease in Student Misconception Quantity

In Figure 1 shows that all concepts tested on a large and small scale about the concept of the form of objects experience a decrease in the quantity of 
students who misconceptions. The average percentage comparison of pretest, posttest, and decreasing student misconceptions between large and small scales is presented in Figure 2 below:

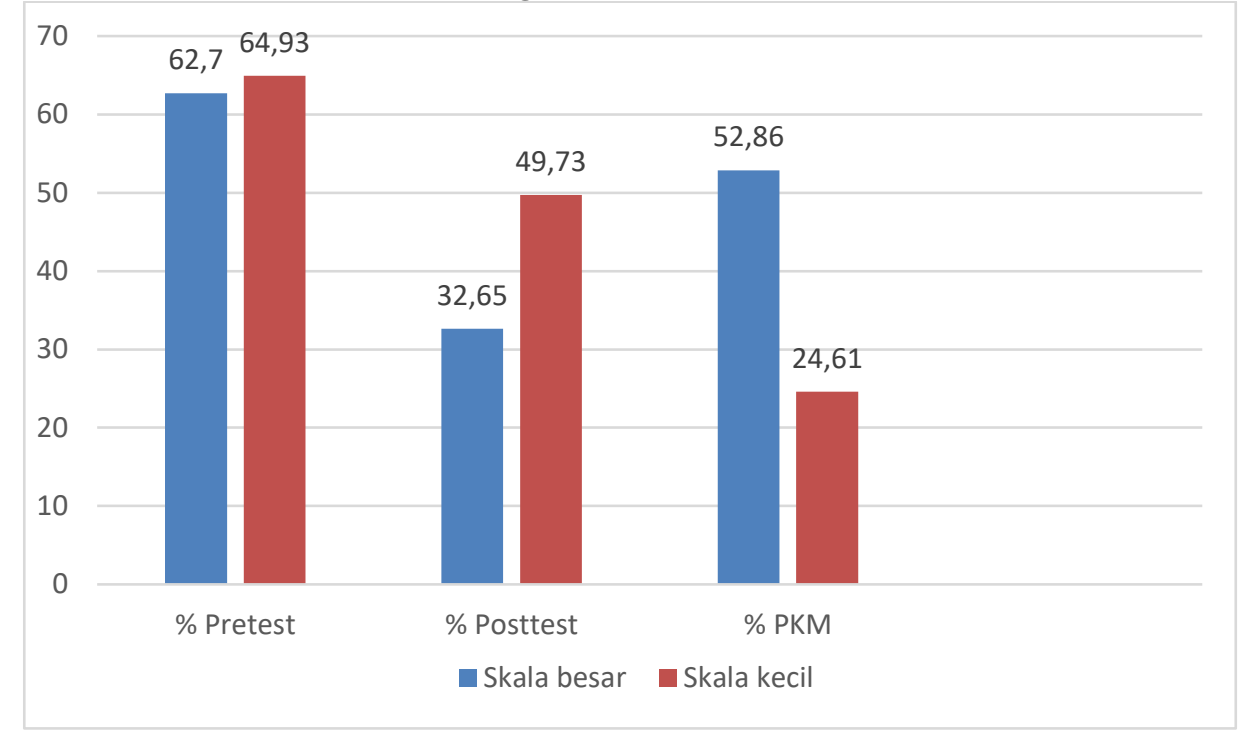

Figure 2

The Percentage of PKM Students large scale and small scale

The results of phase I tests on a large scale many students experienced misconceptions of $62.7 \%$ and the phase II test after instrument revision showed a significant decrease to $32.65 \%$ of students who experienced misconceptions, the presentation of a decrease in the quantity of misconceptions for large scale was $52.86 \%$. the result was quite significant compared to the small scale which decreased by only $24.61 \%$.

\section{DISCUSSION}

The degree of understanding of concepts and indicators in particular is as follows: (1) The answers of students fall into the category of not understanding when: (a) The answer is wrong, the combination of answer options does not indicate a causal relationship. (b) The answer is wrong, the combination of answer options indicates an illogical relationship. (c) No answer. (2) The student's answer belongs to the category of understanding when: The answer is correct, the combination of the choice of the answer indicates a causal relationship that corresponds to the correct concept. (3) The student's answer belongs to the category of misconceptions when: The answer is incorrect, the combination of the answer selection indicates a causal relationship that does not conform to the correct concept $\mathrm{t}^{12}$.

The stage of data collection begins with making a type of question instrument from the editor of the sentence must be adjusted to the level of elementary age ability in reading and understanding the reading of the question. After that the question is distributed to first responders students on a small scale and then on a large scale. Furthermore, the stage of data processing with quantitative techniques calculates how

\footnotetext{
12 Kistiono \& Suhandi. (2013). Penyusunan dan analisis tes pemahaman (understanding) konsep fisika dasar mahasiswa calon guru. Prosiding Seminar Nasional. Yogyakarta: Universitas Negeri Yogyakarta.
} 
much quantity of misconceptions from instruments that have been answered by students.

Based on the results of the research that has been carried out, the ability of teachers in classroom management must be further optimized, the selection of methods in teaching and learning activities must be appropriate in accordance with the objectives of learning in order for the material to be conveyed and received well by students.

\section{CONCLUSION}

From the test results of the instrument, the following data are obtained:

1. The results of phase I tests on a large scale many students experienced misconceptions of $62.7 \%$ and the phase II test after instrument revision showed a significant decrease to $32.65 \%$ of students who experienced misconceptions,

2. Percentage of misconception quantity decrease for large scale is $52.86 \%$. the result was quite significant compared to the small scale which decreased by only $24.61 \%$.

Based on the findings obtained from the results of the study it can be concluded that to know the condition of how much quantity of misconceptions in a learning environment, a tested, valid and reliabel instrument is required. In addition, the type of instrument given is not just a multiple choice question and answer or a 1-level fill, but it takes more than 2 levels to determine the validity of the answer and the respondent's confidence in the answer. Types of problems that have more than 1 level or more can identify misconceptions, and based on the findings, there are still many students who experience misconceptions in the material form objects.

\section{ACKNOWLEDGMENTS}

Researchers thanked the relevant parties including the Ministry of Education and Education who have provided research funds and schools that have given permission to carry out research. Not to forget also the whole team that has helped this research.

\section{BIBLIOGRAPHY}

Helm, H. (1980). Misconceptions in Physics Amongst South African Students. Physics Education, 15(2): 92-105.

Boeha B. B. (1990). Aristotle, Alive and Well in Papua New Guinea science classrooms. Physics Education, 25:280-283.

Halloun IA, dan Hestenes D. (1985). Common sense concepts about motion. American Journal. Physics, 53:1056-1065.

Sabo, H. C., Goodhew, L. M., \& Robertson, A. D. 2016.University Student Conceptual Resources for Understanding Energy.Physical Review Physics Education Research, 12(1): 0101261-01012628.

Tyas, dkk. (2013). Penggunaan Strategi POE (Predict, Discuss, Observe) untuk Memperbaiki Miskonsepsi Fisika. [online]. Tersedia di : http://id.portalgaruda.org/index.p hp?ref=browse\&mod=viewarticle \&article $=342970 . \quad$ Jurnal Pendidikan Sains Pendidikan Kimia Vol 1, No 1 (2013). Diakses pada 10 Oktober 2020.

Andre, T. \& Ding, P. (1991). Student misconceptions, declarative knowledge, stimulus conditions, and problem solving in basic electricity. Contemporary 
Educational Psychology vol 16: 303-313.

Dewi, Suci Zakiah. (2016). Penerapan Strategi Predict, Discuss, Explain, Observe, Discuss, Explain (PDEODE) pada Pembelajaran IPA SD untuk meningkatkan pemahaman Konsep dan Menurunkan Kuantitas Siswa yang Miskonsepsi pada Materi Perubahan Wujud Benda di Kelas V. Tesis. Bandung: Jurusan Pendidikan Dasar SPS UPI Bandung.

Muliyani, R. (2014). Pengaruh penerapan model Pembelajaran predict-observe- explain (POE) berbantuan refutation text terhadap peningkatan pemahaman konsep dan penurunan kuantitas miskonsepsi siswa SMP pada materi fluida statis. Tesis. Bandung: Jurusan Pendidikan Fisika SPS UPI Bandung.

Permendiknas. (2013). Peraturan menteri pendidikan nasional republik indonesia tahun 20013 standar isi pendidikan. Diakses dari: $\quad$ http://bsnpindonesia.org/id/wpcontent/uploads/2013/o6/Perme ndikbud-Nomor-64-tahun-2013tentang Standar-Isi.zip. Oktober 2020.

Kistiono \& Suhandi. (2013). Penyusunan dan analisis tes pemahaman (understanding) konsep fisika dasar mahasiswa calon guru. Prosiding Seminar Nasional. Yogyakarta: Universitas Negeri Yogyakarta. 